\title{
Phylogenetic Relationship of Venturia carpophila, the Causal Agent of Almond Scab from Kashmir Valley as Inferred by ITS nr DNA
}

\author{
M.S. Dar ${ }^{1 *}$, Mushtaq Ahmad ${ }^{2}$, M.D. Shah ${ }^{3}$, Nazir A. Bhat ${ }^{4}$, \\ M.Anwar Khan ${ }^{5}$, and Bilal A. Padder ${ }^{3}$ \\ ${ }^{1}$ Division of Plant Pathology, Faculty of Agriculture, Wadura Sopore, \\ SKUAST-Kashmir 191121, India \\ ${ }^{2}$ Directorate of Extension, SKUAST-Kashmir, Shalimar, Srinagar, 190025, India \\ ${ }^{3}$ Plant Virology and Molecular Plant Pathology Laboratory, Division of Plant Pathology, \\ SKUAST-Kashmir, Shalimar Srinagar 190025, India \\ ${ }^{4}$ Mountain Field Crop Research Centre, Khudwani, Anantnag, 192001, India \\ ${ }^{5}$ Division of Genetics and Plant Breeding, Faculty of Agriculture, Wadura Sopore, \\ SKUAST-Kashmir 191121, India \\ *Corresponding author
}

\section{A B S T R A C T}

\section{Keywords \\ Almond scab, nr DNA, Internal transcribed spacer, Phylogenetics, Venturia carpophila \\ Article Info \\ Accepted: \\ 24 May 2019 \\ Available Online: \\ 10 June 2019}

\begin{abstract}
The fungus Venturia carpophila causes scab in almond. In order to gain insight, an in vitro culture of the fungus has been established and its identity confirmed by its nr DNA. Internal transcribed spacer-ribosomal DNA (ITS-rDNA); the fungal molecular marker was used for molecular analysis. The target region of rDNA (ITS1-5.8S-ITS2) of this species was amplified using universal fungal primers (ITS1 and ITS4). The sequencing of amplified products and their subsequent Basic Local Alignment Search Tool analysis confirmed the identification of species by comparing the sequence of the species with respective species sequences present in Gen Bank. Phylogenetic analysis also confirmed the identification of fungi belongs to Venturiaceae family having $100 \%$ similarity to other $V$. carpophila species.
\end{abstract}

\section{Introduction}

Almond scab caused by the fungus Venturia carpophila (Fisher) (Fisher, 1961) (anamorph, Fusicladium carpophillum) is the most common fungal disease on almonds in Kashmir valley. In India almond is mainly grown in Jammu and Kashmir and Himachal
Pradesh with commercial cultivation confined to the state of Jammu and Kashmir, occupying an area of 5710 ha with an annual production of 13109 metric tonnes (Anonymous, 2018). Almond scab is posing serious problem to the orchardist of Kashmir valley from last few years, in which the severity of disease on leaves and twigs ranges 
from 24.30 and 26.50 percent respectively (Kacho et al., 2017). Symptoms of scab occurs on shoots, leaves and fruits, first on twigs in the first week of May and later on leaves in the second week of May and in severe cases on fruits. Lesions on twigs, are circular to oval with brown centres and slightly raised purple margins, while leaves have small, indistinct, somewhat circular, greenish yellow blotches undersurface. The lesions later enlarge same reaching $10 \mathrm{~mm}$ or more in diameter. With the production of spores, they take an olivaceous appearance and eventually brownish black. On fruit, spots were dark grey to black sooty appearance and coalesced into large dark blotches (Fig. 1). The disease affects fruits and also leads to premature leaf fall resulting in low productivity and poor fruit quality. Management of almond scab is done with dormant treatments of liquid lime sulfur or with copper-agricultural oil mixtures to delay and reduce sporulation of twig lesions (Forster et al., 2009) and within season treatments to prevent new infections. Before the introduction of the quinone outside inhibitor (Qol) fungicides azoxystrobin, trifloxystrobin, and pyraclostrobin, multi-site mode of action fungicides such as captan, ziram, maneb, or wet table sulfur were applied during the petal fall period during leaf emergence and commonly prior to spring rains to manage the disease. Additionally, the single-site mode-of-action methyl benzimidazole carbamate fungicides (e.g., benomyl and thiophanatemethyl) were also used. Resistance against these latter fungicides developed in the pathogen populations in different regions (Ogawa and English, 1991). A number of pathogens from Venturiaceae family has been reported on prunus species causing scab like symptoms such as $F$. pomi, V. carpophila, F. obducens and $F$. cerasi (Schubert et al., 2003). In India, the pathogen was first reported to be causal agent of almond scabin 2017 by (Kacho et al.,
2017) from Kashmir valley. However sexual state of $V$. carpophila has been reported in Australia on apricot trees in 1961 (Fisher, 1961), providing clues about pathogen has capacity to undergo genetic recombination. Based on dominant marker system like RAPD and UP-PCR markers, genetic diversity and divergence within closely related species has clearly show difference between $V$. effuse and $V$. carpophila and also indicated difference between isolates of $V$. carpophila of peach and almond (Chen et al., 2014). However, the result of dominant markers is un reliable because of poor reproducibility, artefactual variation and limitations in understanding of population genetics (Novelo et al., 2010). Some molecular analysis has been used to understand the phylogenetic relationships between $V$. carpophila and other Venturia species, by (Schnabel et al., 1999), however this is less useful for taxonomic interpretation because of Cladosporium caryigenum was taken as out group, which is true anamorph of Venturiaceae. In Kashmir valley no phylogenetic analysis has been carried out on $V$. carpophila and preset study objective was to mine and characterize phylogenetic relationships of $V$. carpophila using ITS nrDNA with other species of Venturiaceae family.

\section{Materials and Methods}

\section{Sample collection and fungal isolation}

Samples were collected from leaves and fruits of almond in 2015 from Kashmir valley. They were first dried with absorbent paper in the laboratory for isolation of the pathogen and stored at $-4{ }^{\circ} \mathrm{C}$ for further processing. The mono conidial isolations were carried out on water agar in Petri plates as described by $(\mathrm{Xu}$ et al., 2008). A small fragment of an infected leaf disc was added to a little amount of distilled water and agitated thoroughly to release conidia. The conidial suspensions 
were diluted to $8 \times 10^{3} \mathrm{ml}^{-1}$ conidia and 200 $\mu l$ of the suspension pipetted onto the water agar plates and spread evenly. These plates were incubated at $20 \pm 1^{\circ} \mathrm{C}$ for $24 \mathrm{~h}$. The individual germinated spores were excised using a cork borer or scalpel blade under a compound microscope and transferred to Petri dishes containing MEA under aseptic conditions. The plates were incubated and maintained at $20 \pm 1^{\circ} \mathrm{C}$. At least 40 isolates from different plant species were collected and maintained for further studies.

\section{DNA extraction, PCR, sequencing}

Total genomic DNA of fungal isolates was extracted using modified CTAB (Cetyltrimethyl ammonium bromide) method (Murray and Thompson, 1980). The ITS nrDNA internal transcribed spacer (ITS) with primers ITS-1 and ITS-4 was amplified and sequenced with primers (White et al., 1990). Comparisons to other nrDNA sequences were conducted with BLAST2.2.24 queries (National Center for Biotechnology Information, National Institute of Health, Bethesda, Maryland). Representative sequence was deposited in GenBank.

\section{Sequence alignment and phylogenetic analysis}

Sequence generated were analysed with other sequences obtained from GenBank (Table 1). A BLAST query was performed to find possible sister groups of the sequenced tax on, and closely related sister groups are included in the phylogenetic analysis (Table 1). A multiple alignment was conducted in MEGA v. 6.02 (Tamura et al., 2013) and analyses were performed. Prior to phylogenetic analysis, ambiguous sequences at the start and the end were deleted and gaps manually adjusted to optimize alignment. ITS rDNA dataset was analysed in this study. Best-fit model of nucleotide evolution $(\mathrm{T} 92+\mathrm{G})$ was selected by Akaike information criterion (AIC) (Posada and Buckley, 2004) in MrModel test 2.3. Bootstrap analysis with 1000 replicates was used to test the statistical support of the branches. The nucleotide sequences reported in this paper were deposited in GenBank and accession number was obtained as MK482360.

\section{Results and Discussion}

During the survey of Kashmir valley, scab like disease on almond which was previously reported by (Kacho et al., 2017) as $C$. carpophillum on the morphological basis was collected. Since the pathogen is reported as anamorph on almond. However, its sexual stage has been reported on apricot by Fisher in 1961 from Australia. This pathogen is difficult to culture because of slow growth rate on culture media which can be masked by other pathogens. The mycelial colony on MEA was dark green turning black after 3035 days of incubation in pure culture (Fig. 2). Number of isolates was cultured and one isolate were sequenced to find its phylogenetic relationship with other closely related species.

\section{Molecular characterization of $V$. carpophila}

To elucidate the relationships between our isolates and other related Venturia species, we carried out an analysis of ITS sequences in which new sequence data of $V$. carpophila was used for present analysis together with other additional sequences obtained from GenBank at NCBI. The accession number of present isolate is MK482360. The GenBank sequences with highest identity to ITS1-5.8 rDNA-ITS2 from $V$. carpophila were identified using BLASTN analysis as shown in (Table 1). The sequence of $V$. carpophila shows 91.22-100\% identity with other Venturia species including V. carpophila. The phylogenetic tree was generated from the 
ITS-5.8 rDNA-ITS2 of $V$. carpophila isolate with other species of Venturiaceae, using neighbor-joining method of the MEGA v. 6.02 (Tamura et al., 2013). The V. carpophila isolate clustered with another $V$. carpophila forming a well-supported (100\% bootstrap) distinct clade (Fig. 3). The isolates of other species like $C$. caryigenum, $V$. martiaffiana and $V$. populina form distinct clade with $100 \%, 98 \%$, and $97 \%$ of the bootstrap value in the family of Venturiaceae, provides supporting data of the taxonomic position of almond scab fungus (Fig. 3). The observed distances between $V$. carpophila and other Venturia species were in a similar range to that observed within the genus Venturia, indicating that the sexual phase of $V$. carpophila places this species within the Venturia genus.

Table.1 Percentage identity between the ITS1-5.8S rDNA-ITS4 sequences of Venturia carpophila and other Venturia species

\begin{tabular}{|l|l|l|}
\hline Accession No. & Organism & \% identity \\
\hline KX261879 & V. carpophila & 100 \\
\hline KX261877 & V. carpophila & 100 \\
\hline KX261873 & V. carpophila & 100 \\
\hline KX261875 & V. carpophila & 100 \\
\hline AF065850 & C. caryigenum & 92.17 \\
\hline AF065851 & C. caryigenum & 92.14 \\
\hline KU985131 & V. martianoffiana & 91.38 \\
\hline KU985132 & V. martianoffiana & 91.80 \\
\hline AY173018 & V. populina & 91.97 \\
\hline KF793783 & V. populina & 91.92 \\
\hline AF065840 & V. pyrina & 91.67 \\
\hline AF065841 & V. pyrina & 91.54 \\
\hline AF065845 & V. nashicola & 91.97 \\
\hline GU086319 & V. nashicola & 91.85 \\
\hline KX815322 & F. pyracanthae & 91.42 \\
\hline AF065838 & V. inaequalis & 91.61 \\
\hline AF531078 & V. inaequalis & 91.54 \\
\hline
\end{tabular}

Fig.1 Symptoms of V. carpophila on Almond (a) fruits (b) Leaves (c) twigs

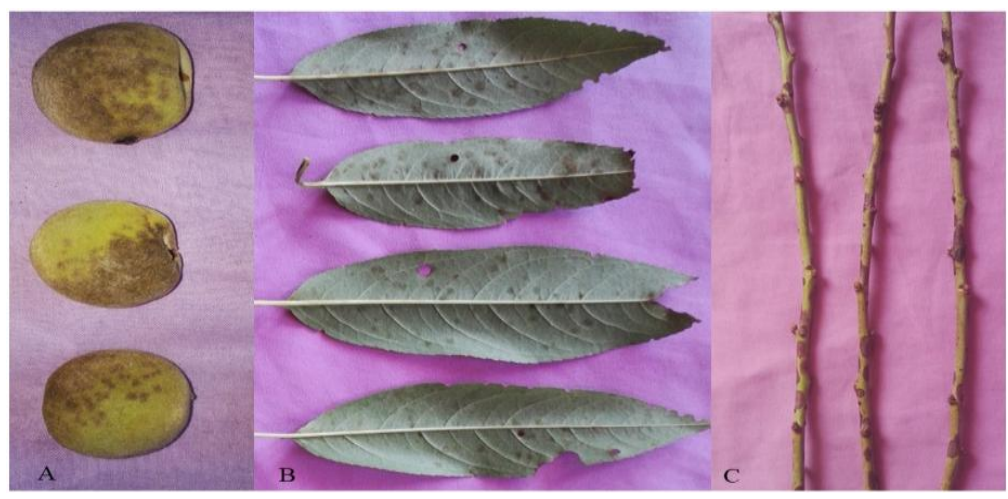


Fig.2 Colony of $V$. carpophila growing on Malt extract agar

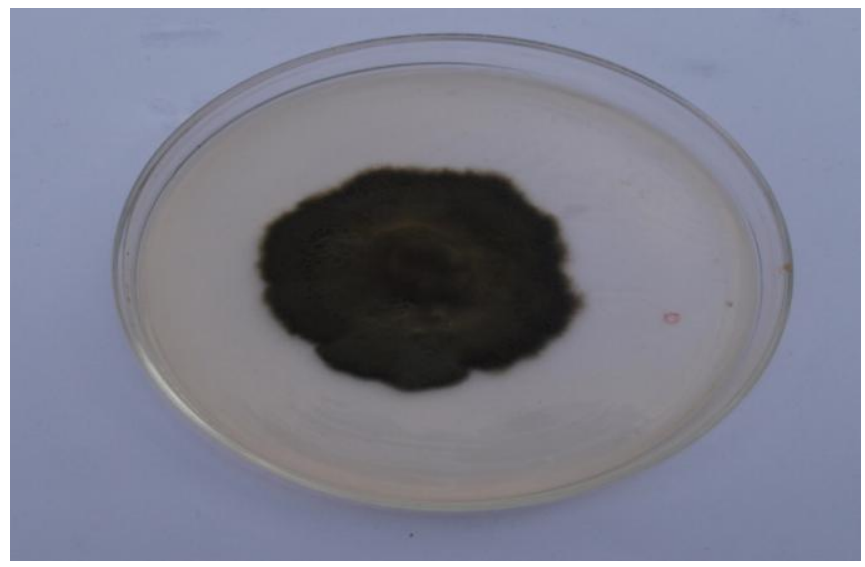

Fig.3 Phylogenetic tree from the ITS1-5.8S rDNA-ITS4 sequences: the tree was constructed using the neighbour-joining method. Bootstrap values (1000 replicates) are indicated above the nodes. Branch lengths are proportional to the genetic distance between the taxa

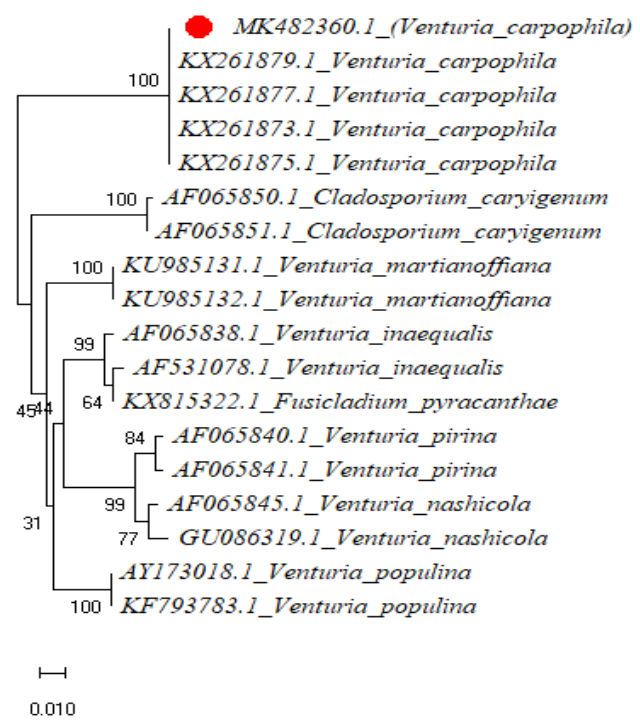

To study the plant-pathogen interaction are liable classification of the pathogens is required. Therefore, phylogenetic classification of an organism is based on previous information of model organisms or related taxon's (Taylor, 1995). In mycology, phylogenetic classification based exclusively on morphology is conflicting. This is also true for Deuteromycetes which makes it difficult to compare related sexual and asexual pathogens (Bruns et al., 1991) and can be overcome with the use of molecular markers. At present, the most reliable sequencing used for this purpose is DNA encoding the small ribosomal subunit (Valente et al., 1999). In our study, the phylogeny of the almond scab fungus based on ITS1-5.8 rDNA-ITS2region was in consistent with the phylogeny based on the ITS region and are in conformity with (Beck et al., 2005; Braun et al., 2003; Schubert et al., 2003; Schubert and Braun 2002), they put rDNA ITS data of some 
cladosporioid Venturia anamorphs in a more comprehensive context of Cladosporium-like fungi and concluded that these are true members of the Venturiaceae. Schubert et al.,(2003) described and discussed the taxonomic value of these features for Venturia anamorphs in detail, listed morphologically intermediate species and concluded that a separation based on conidial formation and proliferation of the conidiogenous cells is not tenable. As far as possible, anamorphs should reflect monophyletic holomorphic taxa (Reynolds 1993). However, such reassessments and reevaluations have to be made for all groups of ascomycetes individually. The treatments of cercosporoid Mycosphaerella anamorphs (Crous et al., 2000, Crous, et al., 2001, Crousand Braun 2003) and Venturia anamorphs (Schubert et al., 2003) are first examples. Moreover, the use of variable sequences like ITS1-5.8S rDNA-ITS2 to confirm the phylogeny of $V$. carpophila, established that this species belongs tothe Venturia genus. This is valuable information for studying the interaction between $V$. carpophila and almond trees since previous information known from species of the Venturia genus can be applied.

\section{References}

Anonymous 2018. Directorate of Horticulture, Government of Jammu and Kashmir.

Beck, A., Ritschel. A., Schubert. K., Braun, U. and Triebel. D. 2005. Phylogenetic relationships of the anamorphic genus Fusicladiums. 1. as inferred by ITS nrDNA data. Mycological Progress 4(2): 111-116

Braun U, Ritschel A. and Schubert, K. 2002. Proposal to conserve the generic name Fusicladium against Spilocaea (Hyphomycetes). Taxon51: 557.

Braun, U., Crous, P.W., Dugan, F.,
Groenewald, J.Z. and de Hoog, G. S. 2003. Phylogeny and taxonomy of Cladosporium-like hyphomycetes, including Davidiella gen. nov., the teleomorph of Cladosporium s. str. Mycological Progress 2:3-18

Bruns, T.D., White, T.J. and Taylor, J.W. 1991. Fungal molecular systematics. Annu. Rev. Ecol. Syst. 22, 525-564.

Chen, C., Bock, C.H., Brannen, P.M., Adaskaveg, J.E., Hotchkiss, M.W., Brewer, M. T. and Wood, B. W. 2014. Genetic variability among populations of Fusicladium species from different host trees and geographic locations in the USA. MycolProg 13:1179-1190.

Crous, P. W., Aptroot, A., Kang, J. C, Braun, U. and Wing field, M. J. 2000. The genus Mycosphaerella and its anamorphs. Studies in Mycology45: 107-121.

Crous, P. W., Kang, J. C. and Braun, U. 2001. A phylogenetic redefinition of anamorph genera in Mycosphaerella based on ITS rDNA sequences and morphology. Mycologia93: 10811101.

Crous, P.W. and Braun, U. 2003. Mycosphaerellaand its anamorphs: 1. Names published in Cercospora and Passalora. - CBS Biodiversity Series 1: $1-571$.

Fisher. E. E. 1961. Venturia carpophila sp. nov., the ascigerous state of the apricot freckle fungus. Trans. $\mathrm{Br}$. Mycol. Soc. 44:337-342.

Forster, H., Connell, J. H. and Adaskaveg, J. E. 2009. Dormant treatments as a component of integrated management of almond scab caused by Fusictadosporium carpophilum. (Abstr.) Phytopathology, 99: S36.

Kacho, N. F., Ahmed, K., Hussain, M., Bhat, M. A., Banday, S., and Qazi N. A. 2017.First record of scab disease of almond caused by Cladosporium 
carpophilumin India. Indian Phytopath. 70:403-404.

Murray, M.G. and Thompson, W.F. 1980. Rapid isolation of high molecular weight plant DNA. Nucleic Acids Research8: 4321-4325.

Novelo, N.D., Gomelsky, B. and Pomper, K. W. 2010. Inheritance and reliability of random amplified polymorphic DNAmarkers in two consecutive generations of common carp (Cyprinus carpio L.). Aquac Res 41: 220-226

Ogawa, J. M., and English, H. 1991. Diseases of Temperate Zone Tree Fruit and Nut Crops. University of California. Division of Agriculture and Natural Resources, Oakland. Publ. 3345.

Posada, D. and Buckley, T.R. 2004. Model selection and model averaging in phylogenetics: advantages of Akaike information criterion and Bayesian approaches over likelihood ratio tests. Systemat. Biol. 53, 793-808.

Reynolds, D. R. 1993. The fungal holomorph: an overview. In Reynolds, D.R. and Taylor, J.W., (eds) The Fungal Holomorph: mitotic, meiotic and pleomorphic speciation in fungal systematics, pp. 15-25. CAB International, Wallingford.

Schnabel, G., Schnabel, E. L. and Jones, A. L. 1999. Characterization of ribosomal DNA from Venturia inaequalis and its phylogenetic relationship to rDNA from other tree-fruit Venturia species. Phytopathology 89: 100-108

Schubert, K., Ritschel, A. and Braun, U. 2003. A monograph of Fusicladium s. lat. (hyphomycetes). Schlechtendalia 9:1-132

Tamura, K., Peterson, D., Peterson, N., Stecher, G., Nei, M. and Kumar, S. 2013. MEGA v. 6.02: molecular evolutionary genetics analysis using maximum likelihood, evolutionary distance, and maximum parsimony methods. Mololecular Bioliology Evolution, 28: 2731-2739

Taylor, J.W. 1995. Molecular phylogenetic classification of fungi. Arch. Med. Res. 26, 307-314.

Valente, P., Ramos, J.P. and Leoncini, O. 1999. Sequencing as a tool in yeast molecular taxonomy. Can. J. Microbiol. 45, 949-958.

White, T. J., Bruns, T., Lee, S. and Taylor, J. 1990. Amplification and direct sequencing of fungal ribosomal RNA genes for phylogenetics, In: PCR Protocol: A Guide to Methods and Applications, ed. by M. A. Innis, D. H. Gelf and, J. J. Sninsky and T. J. White, pp 315-322. Academic Press, New York, USA.

$\mathrm{Xu}, \mathrm{X}$. , Yang, J., Vijay, T., Roberts, A. and Barbara, D. J. 2008. Population variation apple scab (Venturia inaequalis) isolates from Asia and Europe. Plant Disease 92(2): 247-252.

\section{How to cite this article:}

Dar, M.S., Mushtaq Ahmad, M.D. Shah, Nazir A. Bhat, M.Anwar Khan and Bilal A. Padder. 2019. Phylogenetic Relationship of Venturia carpophila, the Causal Agent of Almond Scab from Kashmir Valley as Inferred by ITS nr DNA. Int.J.Curr.Microbiol.App.Sci. 8(06): 29132919. doi: https://doi.org/10.20546/ijcmas.2019.806.350 